\title{
Development of the design and processing technology of an innovative energy gate valve
}

\author{
Opracowanie konstrukcji i technologii obróbki \\ innowacyjnej zasuwy energetycznej
}

\author{
STANISŁAW ADAMCZAK \\ EDWARD MIKO \\ WŁODZIMIERZ MAKIEŁA \\ ŁUKASZ NOWAKOWSKI \\ MICHAt SKRZYNIARZ \\ MAREK JAREMA \\ JACEK ŚWIDERSKI \\ TOMASZ DOBROWOLSKI \\ CZESŁAW WÓJCIK*
}

DOI: https://doi.org/10.17814/mechanik.2020.12.19

The article presents the results of the research project in cooperation between Kielce University of Technology and Chemar Armatura Sp. z o.o. Project co-financed by european funds was entitled: "Putting into the production of an innovative series of energy wedge gate which is equipped with two-part wedge and swing disk, as a result of R\&D works at Chemar Armatura".

KEYWORDS: wedge, gate valve, tightness, energy consumption, weight reduction, CAD/CAM

W artykule przedstawiono wyniki pracy badawczej prowadzonej przez Politechnikę Świętokrzyską w Kielcach oraz Chemar Armatura Sp. z o.o., dofinansowanej z funduszy europejskich w ramach projektu pt. „Wdrożenie do produkcji w firmie Chemar Armatura innowacyjnego typoszeregu zasuw klinowych wyposażonych w klin dwudzielny z przesuwanymi dyskami wahliwymi, jako wynik zleconych prac B+R". SŁOWA KLUCZOWE: kiln, zasuwa, szczelność, energochłonność, redukcja masy, CAD/CAM

\section{Wprowadzenie}

Zasuwy klinowe z powierzchniami uszczelniającymi klina i siedlisk metal-metal są przeznaczone do odcinania przepływu czynnika o wysokich parametrach (takich jak ciśnienie i temperatura) w odcinkach rurociągów służących do transportu czynników ciekłych i gazowych. Ze względu na zastosowanie zasuwy używa się tylko w dwóch położeniach: całkowicie otwartej lub zamkniętej. Nie nadają się one do regulacji przepływu. Przepływ czynnika przy klinie znajdującym się w położeniu pośrednim może wywoływać drgania i uderzenia klina, które z kolei mogą doprowadzić do uszkodzenia metalowych powierzchni uszczelniających, a w konsekwencji - do utraty szczelności zamknięcia zasuwy.

Szczelność zamknięcia zasuwy uzyskuje się przez zapewnienie odpowiedniej struktury geometrycznej powierzchni uszczelniających klina i siedlisk, takiej jak płaskość, falistość i chropowatość. Z rodzajem materiału zastosowanego na te elementy i stereometrią powierzchni związany jest współczynnik tarcia, a w konsekwencji - także siła niezbędna do zamknięcia i otwarcia zasuwy. Od kinematyki procesu zamykania i otwierania zasuwy zależy trwałość i niezawodność węzła klin-siedliska.

\section{Badania stanu techniki dotyczące rozwiązań konstrukcyjnych zasuw stosowanych w przemyśle energetycznym}

Powszechne są rozwiązania zasuw $\mathrm{z}$ klinami dwudzielnymi (CN104832672A, CN105318025A, CN106763849A, CN204459223U, CN205260884U), w których sprężyny łączą i wywierają nacisk na przesuwne części klina, zazwyczaj w postaci dysków. Wadą takich konstrukcji klinów w zasuwach do odcinania

\footnotetext{
* Prof. dr hab. inż. Stanisław Adamczak, adamczak@tu.kielce.pl, https://orcid.org/0000-0002-7797-6330 - Katedra Technologii Mechanicznej i Metrologii, Wydział Mechatroniki i Budowy Maszyn Politechniki Świętokrzyskiej, Kielce, Polska Dr hab. inż. Edward Miko, prof. PŚk, emiko@tu.kielce.pl, https://orcid.org/0000-0003-0339-2225 - Katedra Technologii Mechanicznej i Metrologii, Wydział Mechatroniki i Budowy Maszyn Politechniki Świętokrzyskiej, Kielce, Polska

Dr hab. inż. Włodzimierz Makieła, wmakiela@tu.kielce.pl, https://orcid.org/0000-0002-5100-6184 - Katedra Technologii Mechanicznej i Metrologii, Wydział Mechatroniki i Budowy Maszyn Politechniki Świętokrzyskiej, Kielce, Polska

Dr inż. Łukasz Nowakowski, lukasn@tu.kielce.pl, https://orcid.org/0000-0002-2425-7295 - Katedra Technologii Mechanicznej i Metrologii, Wydział Mechatroniki i Budowy Maszyn Politechniki Świętokrzyskiej, Kielce, Polska

Dr inż. Michał Skrzyniarz, mskrzyniarz@tu.kielce.pl, https://orcid.org/0000-0003-4590-5842 - Katedra Technologii Mechanicznej i Metrologii, Wydział Mechatroniki i Budowy Maszyn Politechniki Świętokrzyskiej w Kielcach, Polska

Mgr inż. Marek Jarema, mjarema@tu.kielce.pl - Katedra Technologii Mechanicznej i Metrologii, Wydział Mechatroniki i Budowy Maszyn Politechniki Świętokrzyskiej, Kielce, Polska

Mgr inż. Jacek Świderski, swiderski@tu.kielce.pl - Katedra Technologii Mechanicznej i Metrologii, Wydział Mechatroniki i Budowy Maszyn Politechniki Świętokrzyskiej, Kielce, Polska

Mgr inż. Tomasz Dobrowolski, t.dobrowolski@tu.kielce.pl - Katedra Technologii Mechanicznej i Metrologii, Wydział Mechatroniki i Budowy Maszyn Politechniki Świętokrzyskiej, Kielce, Polska

Czesław Wójcik - Katedra Technologii Mechanicznej i Metrologii, Wydział Mechatroniki i Budowy Maszyn Politechniki Świętokrzyskiej, Kielce, Polska
} 
przepływu czynnika o wysokim ciśnieniu czy temperaturze jest to, że sprężyny się rozhartowują, powodując utratę własności użytkowych zasuwy.

Znane jest z literatury CN203532821A rozwiązanie klina dwudzielnego mającego korpus z gniazdem montażowym trzpienia zasuwy (rys. 1). W korpusie klina jest przelotowy otwór, w którym osadzony jest trzpień w kształcie hantla, a jego końce są osadzone w gniazdach wahliwych dysków, usytuowanych symetrycznie po obu stronach klina. Wychylenia dysków są ograniczone poprzez wypusty górnej i dolnej części korpusu klina. Dyski swoimi płaskimi zewnętrznymi powierzchniami współpracują z siedliskami zasuwy, otwierając lub zamykając przepływ medium.

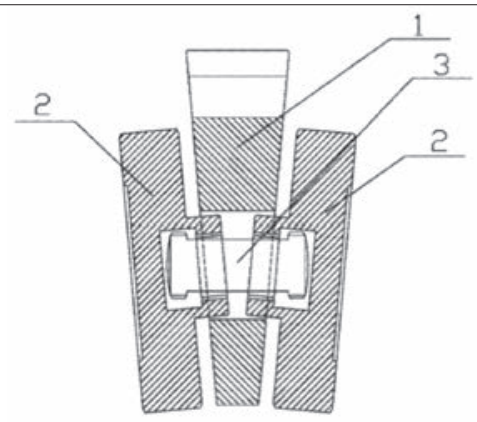

Fig. 1. A two-part wedge with a body with a mounting seat for the mandrel: 1 - wedge body, 2 - disk, 3 - mandrel

Rys. 1. Klin dwudzielny mający korpus z gniazdem montażowym na trzpień: 1 - korpus klina, 2 - dysk, 3 - trzpień

\section{Teoretyczna analiza wybranych parametrów zaprojektowanej zasuwy}

Podstawowymi parametrami charakteryzującymi funkcjonalność działania armatury zaporowej są: szczelność zamknięcia, szczelność uszczelnienia dławnicowego, wytrzymałość korpusu na działanie ciśnienia wewnętrznego i obciążeń od rurociągu, trwałość i niezawodność.

Przeanalizowano wybrane elementy konstrukcyjne zasuwy, tj.: kadłub, klin i trzpień.

\section{Szczelność zamknięcia}

Aby zamknięcie zasuw klinowych było szczelne, elementy węzła klin-kadłub należy wykonać zgodnie ze specyfikacją pod względem wymiarowym, by zapewnić pokrycie powierzchni uszczelniających klina i siedlisk w kadłubie. 0 prawidłowym działaniu tego węzła decydują kąt klina i kąt pomiędzy siedliskami w kadłubie $\left(\alpha=4^{\circ}\right)$ oraz wymiar w osi tych elementów $(A=65 \mathrm{~mm})$. Powierzchnie uszczelniające klina i siedlisk powinny - według specyfikacji - charakteryzować się odchyłką płaskości mniejszą niż $5 \mu \mathrm{m}$ oraz chropowatością $R a \leq 0,2 \mu \mathrm{m}$.

$\mathrm{W}$ ramach realizowanej pracy badawczej zmierzono kąt klina i płaskość powierzchni uszczelniających na współrzędnościowej maszynie pomiarowej. Odchyłka płaskości powierzchni uszczelniających wyniosła 4,5 $\mu \mathrm{m}$, a kąt klina: 7,999 .

W wyniku pomiarów i analizy dokumentacji stwierdzono, że odchyłka płaskości otrzymanej po docie- raniu powierzchni uszczelniającej klina jest zgodna $\mathrm{z}$ wymaganiami założonymi $\mathrm{w}$ dokumentacji konstrukcyjnej. Odchyłka kąta klina od wymiaru nominalnego wynosi $0,001^{\circ}\left(3,6^{\prime \prime}\right)$. Przyjmując założenie tolerancji ogólnych według PN-EN 22768-1 dla klasy dokładnej odchyłki graniczne wynoszą \pm 10 ', zatem wymaganie jest spełnione. Powierzchnia uszczelniająca klina po docieraniu ma charakter losowy izotropowy. Rozkład rzędnych powierzchni jest zbliżony do rozkładu normalnego, o czym świadczy wartość parametru $S k u=3,77$. W rozkładzie gęstości widmowej mocy brak jednej dominującej składowej. Uzyskano zbliżone wartości parametrów $S a=0,560 \mu \mathrm{m}$ dla powierzchni i $R a=0,534 \mu \mathrm{m}$ dla profilu.

\section{Szczelność uszczelnienia dławnicowego}

Dla szczelności uszczelnienia dławnicowego istotna jest dokładność wymiarowo-kształtowa trzpienia oraz stan stereometrii powierzchni trzpienia współpracującej z pakietem uszczelnienia.

Pomiary chropowatości powierzchni trzpienia oraz prostoliniowości tworzących części trzpienia współpracującej z uszczelnieniem dławnicowym przeprowadzono w czterech położeniach co $90^{\circ}$ na profilometrze stykowym.

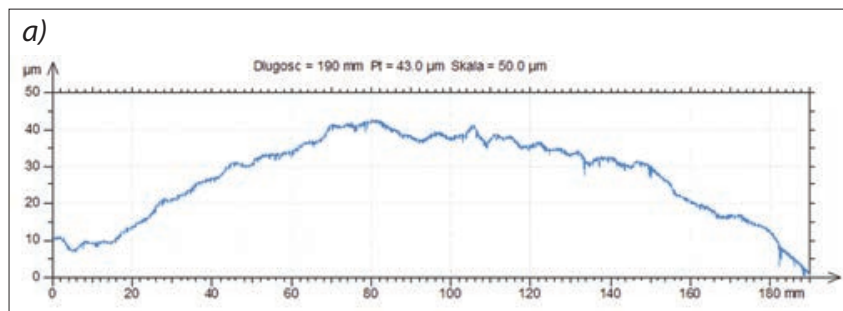

b)

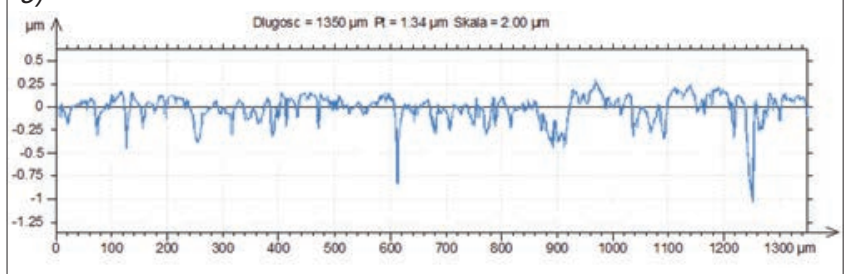

Fig. 2. An exemplary measurement result of: a) straightness of the mandrels, b) roughness of the surface of the mandrel mating with the gland packing

Rys. 2. Przykładowy wynik pomiaru: a) prostoliniowości tworzących trzpienia, b) chropowatości powierzchni trzpienia współpracującej z uszczelnieniem dławnicowym

Otrzymana w wyniku rolowania powierzchnia trzpienia współpracująca z uszczelnieniem dławnicowym ma charakter losowy izotropowy ze składową kierunkowości wynikającą z poprzedniej operacji (toczenia). Wynik pomiaru wartości parametru $R a=0,076 \mu \mathrm{m}$ jest zgodny ze specyfikacją.

\section{Opracowanie projektu konstrukcji klina dwudzielnego}

Celem badań było opracowanie dwudzielnego klina zasuwy z przesuwanymi dyskami wahliwymi, usprawniającego kinematyke procesu zamykania zasuwy dzięki możliwości kompensacji błędów 


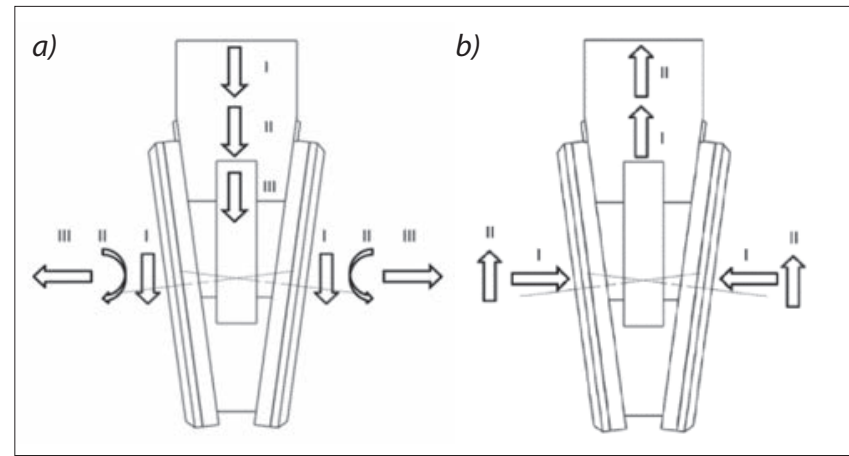

Fig. 3. Phases of: $a$ ) closing the gate valve, $b$ ) opening the gate valve Rys. 3. Przebieg faz: $a$ ) zamykania zasuwy, $b$ ) otwierania zasuwy

wykonania siedlisk w kadłubie zasuwy oraz otwierania pozwalającego na zmniejszenie siły osiowej niezbędnej do wyrwania klina z siedlisk kadłuba.

W trakcie zamykania zasuwy (rys. $3 a$ ) klin dwudzielny wsuwa się pomiędzy siedliska korpusu zasuwy (faza I). Po doprowadzeniu do kontaktu dysków z siedliskami powierzchnie czołowe dysków - w których zastosowano połączenie wahliwe - ustawiają się równolegle do powierzchni siedlisk (faza II), zapewniając lepsze dopasowanie. Następnie korpus jest wciskany pomiędzy nieprzemieszczające się $\mathrm{w}$ kierunku pionowym obsady dysków i rozpiera je na boki w kierunku poziomym (faza III), co powoduje dociskanie powierzchni uszczelniających dysków do powierzchni uszczelniających siedlisk.

$\mathrm{W}$ trakcie otwierania zasuwy (rys. $3 b$ ) korpus jest wyciągany z przestrzeni między dyskami, które pozostają nieruchome, luzując je w kierunku poziomym (faza I). To powoduje zmniejszenie siły docisku powierzchni uszczelniających dysków do powierzchni uszczelniających siedlisk i umożliwia łagodne wysunięcie klina dwudzielnego do góry w kierunku pionowym (faza II).

Klin dwudzielny zasuwy ma korpus z dwiema powierzchniami ustawionymi względem siebie pod kątem. W korpusie jest gniazdo współpracujące $\mathrm{z}$ trzpieniem zasuwy. Korpus ma po obu stronach rowki, w których zamontowano pierścienie ślizgowo-dystansowe. Po obu stronach korpusu są również gniazda z naciętymi rowkami zamka, w których montowana jest obsada. Obsada ma z przodu wklęsła powierzchnię sferyczną, a od tyłu - rowek zawleczki oraz owalny wypust zamka z wypukłą powierzchnią sferyczną.

W osi obsady jest otwór. Montaż obsady w korpusie jest realizowany za pomocą zamka, który składa się z owalnego rowka zamka znajdującego się po obu stronach korpusu oraz owalnego wypustu zamka na obsadzie. Zapięcie zamka odbywa się poprzez wprowadzenie owalnego wypustu zamka obsady w owalny otwór w korpusie i obrócenie obsady o $90^{\circ}$. Przed rozpięciem obsady z korpusem zabezpiecza zawleczka, wprowadzona $\mathrm{w}$ rowek $\mathrm{w}$ obsadzie. Zawleczka blokuje obrót obsady względem korpusu.

Obsada może się przesuwać wzdłużnie po powierzchni pierścieni w gnieździe korpusu o ok. $5 \mathrm{~mm}$. Obsada ma wklęsłą powierzchnię sferyczną, współpracująca z wypukłą powierzchnią sferyczną dysku, by umożliwić

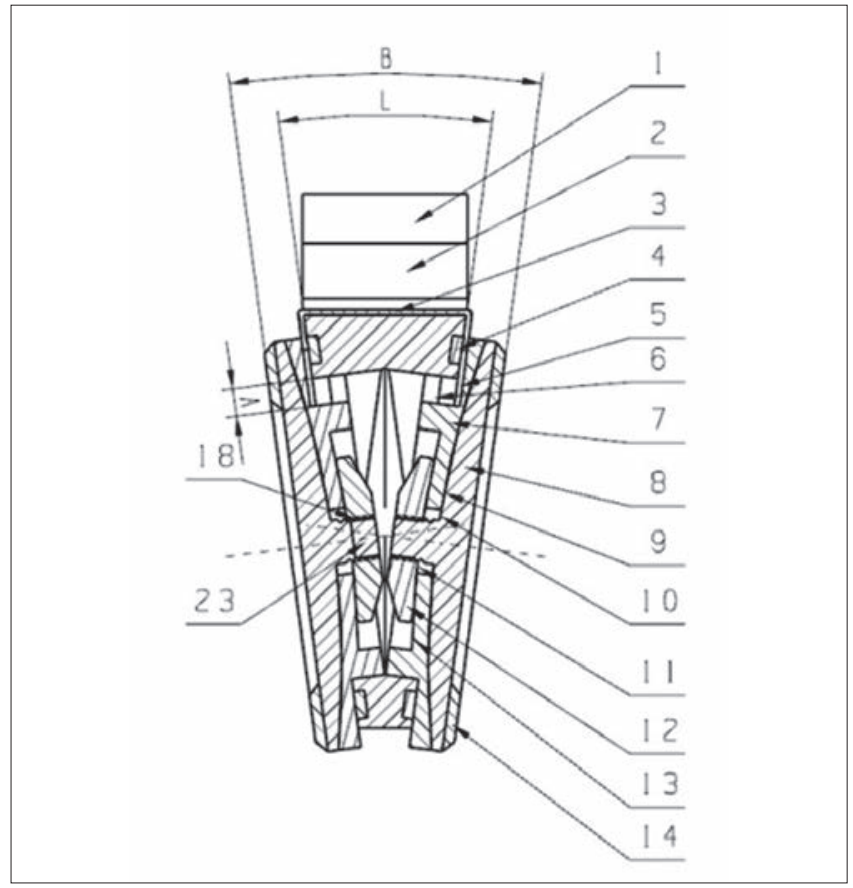

Fig. 4. Double wedge in cross-section

Rys. 4. Dwudzielny klin w przekroju

wahliwą zmianę położenia dysku względem obsady. Dysk jest przytwierdzony do obsady za pomocą gwintowanego trzpienia dysku oraz gwintowanego otworu w nakrętce, której wklęsła powierzchnia sferyczna podczas wahliwego przemieszczania się dysku współpracuje z wypukłą powierzchnią sferyczną obsady. Na zewnętrznej powierzchni dysku jest napoina.

Elementami klina dwudzielnego (rys. 4) są: 1 - korpus, 2 - gniazdo, 3 - zawleczka, 4 - pierścień, 5 - rowek zawleczki, 6 - rowek zamka, 7 - obsada, 8 - dysk, 9 - wklęsła powierzchnia sferyczna obsady (7), 10 wypukła powierzchnia sferyczna dysku (8), 11 - wklęsła powierzchnia sferyczna nakrętki (12), 12 - nakrętka, 13 - wypukła powierzchnia sferyczna obsady (8), 14 - napoina.

Zdjęcia (rys. 5 i 6) prezentują prototyp klina dwudzielnego $\mathrm{z}$ przesuwnymi dyskami wahliwymi na bazie patentu Politechniki Świętokrzyskiej i Chemar Armatura A1 423240.

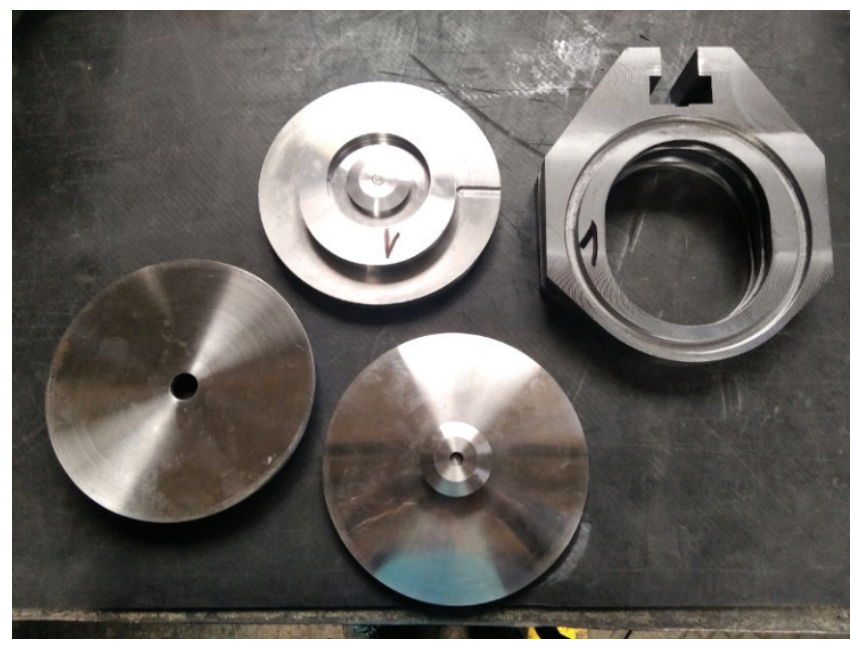

Fig. 5. Components of a double wedge with sliding oscillating discs Rys. 5. Elementy składowe klina dwudzielnego z przesuwnymi dyskami wahliwymi 


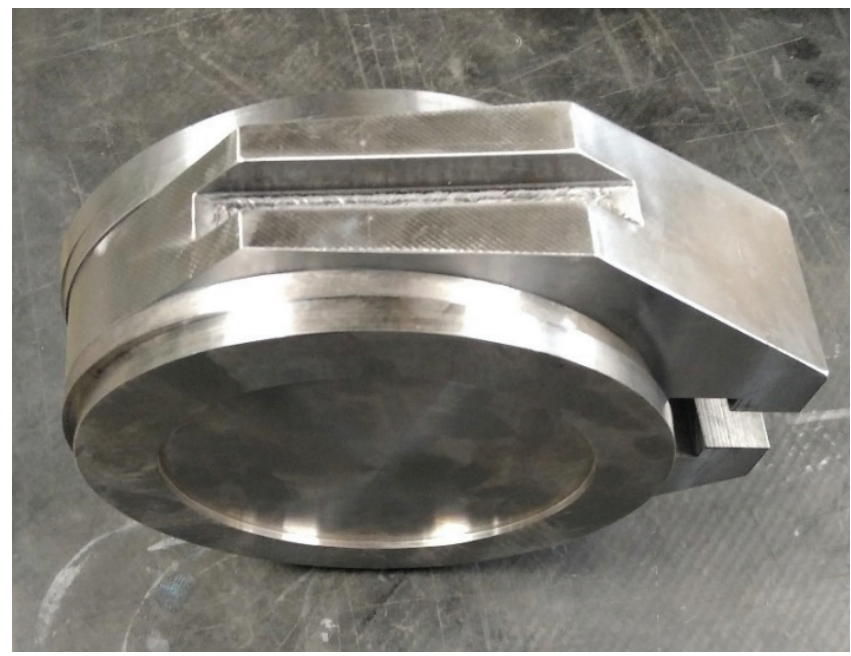

Fig. 6. Side view of the assembled double wedge with sliding oscillating discs

Rys. 6. Widok z boku zmontowanego klina dwudzielnego z przesuwnymi dyskami wahliwymi

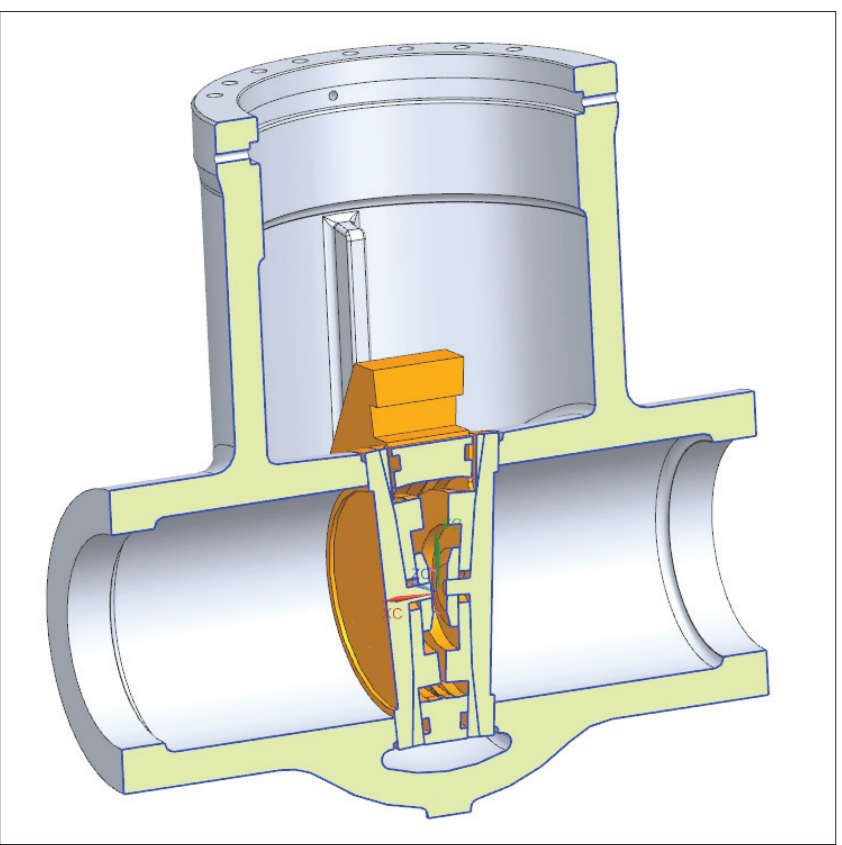

Fig. 7. Cross-section of a double wedge installed in the body of the DN150 PN100 valve

Rys. 7. Przekrój klina dwudzielnego zamontowanego w kadłubie zasuwy DN150 PN100

Na rys. 7 przedstawiono projekt konstrukcyjny klina dwudzielnego do zasuwy DN150 PN100. W ramach prac konstrukcyjnych opracowano modele 3D: korpusu, zawleczki, pierścienia, obsady, dysku i nakrętki.

\section{Opracowanie technologii obróbki części klina dwudzielnego w programie CAD/CAM}

Pierwszy etap badań polegał na opracowaniu ramowego procesu technologicznego wybranych części składowych zasuwy. Powstał spis operacji i zbiegów niezbędnych do wytworzenia poszczególnych elementów klina dwudzielnego. Następnie prace skupiły się na opracowaniu w systemach CAD/CAM procesu obróbki wybranych części nowej zasuwy na podstawie ramowego procesu technologicznego. Prace projektowe przeprowadzono w programie MasterCAM, który jest programem typu CAM stosowanym do tworzenia technologii obróbki na obrabiarki CNC, na podstawie której postprocesor generuje ścieżki obróbkowe sterujące pracą maszyny. W trakcie tworzenia procesu technologicznego w systemie CAM wstępnie dobrano parametry skrawania, zalecane przez producentów narzędzi. Po wprowadzeniu wstępnych parametrów skrawania do programu MasterCAM wybrano strategię obróbki i wygenerowano ścieżki obróbkowe dla poszczególnych operacji, które następnie zweryfikowano.

Po opracowaniu i weryfikacji procesu obróbki wybranych części nowej zasuwy z wykorzystaniem systemów CAD/CAM zoptymalizowano parametry skrawania oraz ścieżki obróbkowe elementów składowych klina dwudzielnego. Optymalizacja została przeprowadzona w celu: skrócenia czasu obróbki, lepszego wykorzystania krawędzi skrawającej narzędzi, poprawy produktywności i stabilności obróbki oraz uniknięcia zbyt dużych naddatków na obróbkę wykończeniową.

\section{Przykładowy opis technologii obróbki korpusu klina}

Opisana technologia zostanie zrealizowana na pionowym centrum frezarskim Harnaś R550 w pięciu zamocowaniach.

Zamocowanie 1 (rys. 8): Półfabrykatem wyjściowym do wykonania klina będzie wałek o: średnicy $\varnothing 250 \mathrm{~mm}$ i długości $80 \mathrm{~mm}$, zamocowany w uchwycie trójszczękowym typu 3234-315-11.

W zamocowaniu 1 zostaną wykonane operacje: planowania powierzchni czołowej, frezowania zgrubnego i wykończeniowego konturu zewnętrznego klina według rys. 8 na głębokość $65 \mathrm{~mm}$, frezowania przelotowo na powierzchniach bocznych frezem teowym dwóch kanałów prowadzących klin o długości $90 \mathrm{~mm}$, szerokości $15 \mathrm{~mm}$ i głębokości 13,5 mm oraz wykonania kieszeni o średnicy $\varnothing 100 \mathrm{~mm}$ na głębokość $65 \mathrm{~mm}$ pod frezowanie kształtowe konturu krzywoliniowego $140 \mathrm{~mm} \times 120 \mathrm{~mm}$.

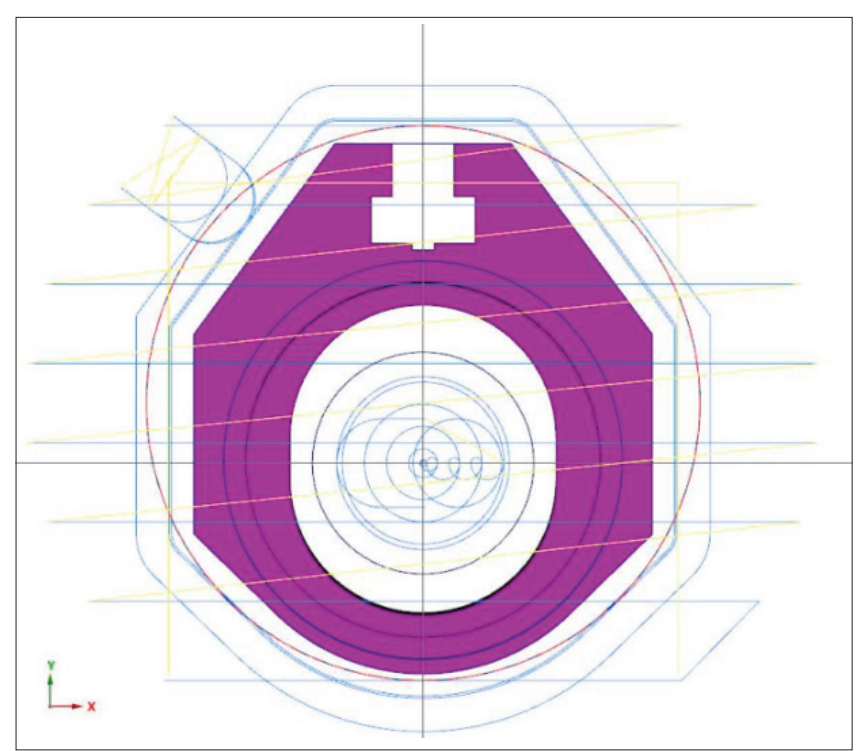

Fig. 8. Exemplary machining paths for a wedge - mounting 1 Rys. 8. Przykładowe ścieżki obróbkowe dla klina - zamocowanie 1 
Zamocowanie 2: Półfabrykatem w zamocowaniu 2 będzie obrobiony z jednej strony w zamocowaniu 1 wałek o: średnicy $\varnothing 250 \mathrm{~mm}$ i długości $80 \mathrm{~mm}$, zamocowany za obrobiony kontur klina w imadle maszynowym z dociskiem szczęki typu 6523. Zostanie wykonana operacja planowania powierzchni czołowej na wysokość 63,5 mm.

Zamocowanie 3: Półfabrykatem wyjściowym do wykonania klina będzie obrobiony w zamocowaniu 2 korpus klina, zamocowany pionowo w imadle maszynowym z dociskiem szczęki typu 6523. Zostanie przeprowadzona obróbka rowka teowego na górnej powierzchni klina, składająca się z: frezowania kanału przelotowego o wymiarach $28 \mathrm{~mm} \times 45 \mathrm{~mm}$, frezowania przelotowo kanału teowego o wymiarach $47 \mathrm{~mm} \times 21 \mathrm{~mm}$ oraz frezowania przelotowo kanału o wymiarach $10 \mathrm{~mm} \times 3 \mathrm{~mm}$ pod zawleczkę zabezpieczająca.

Frezarka zamocowanie 4 (rys. 9): Półfabrykatem wyjściowym do wykonania klina będzie obrobiony w zamocowaniu 3 korpus klina, zamocowany poziomo w imadle maszynowym z dociskiem szczęki typu 6523 na specjalnych podkładkach klinowych.

Zostanie przeprowadzona obróbka powierzchni klina, nachylonej pod kątem $31,7^{\circ}$. Obróbka będzie się składała z: frezowania powierzchni czołowej, frezowania konturu krzywoliniowego o wymiarach $140 \mathrm{~mm} \times 120 \mathrm{~mm}$, frezowania rowka o wymiarach $10 \mathrm{~mm} \times 5 \mathrm{~mm}$ na średnicy $\varnothing 170 \mathrm{~mm}$ na powierzchni czołowej oraz frezowania podcięcia pod zamek obsady $8 \mathrm{~mm} \times 140 \mathrm{~mm}$ na głębokość $10 \mathrm{~mm}$.

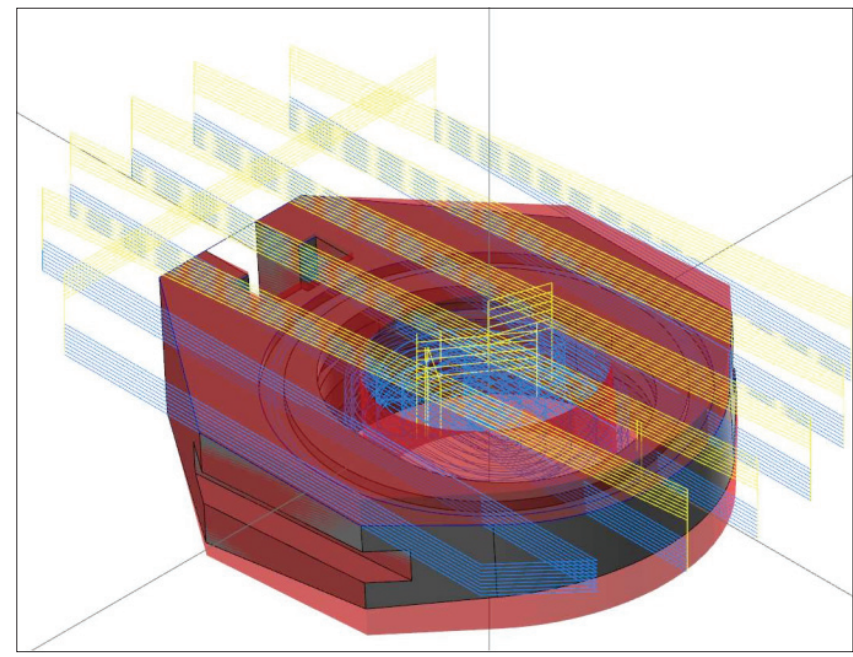

Fig. 9. Machining paths for the wedge - mounting 4 Rys. 9. Ścieżki obróbkowe dla klina - zamocowanie 4

Zamocowanie 5: Półfabrykatem wyjściowym do wykonania klina będzie obrobiony $\mathrm{w}$ zamocowaniu 4 korpus klina, zamocowany poziomo $\mathrm{w}$ imadle precyzyjnym z dociskiem szczęki typu 6523 na specjalnych podkładkach klinowych. Zostaną przeprowadzone te same operacje, co $\mathrm{w}$ zamocowaniu 4, tj.: frezowanie powierzchni czołowej, frezowanie konturu krzywoliniowego o wymiarach $140 \mathrm{~mm} \times 120 \mathrm{~mm}$, frezowanie rowka o wymiarach $10 \mathrm{~mm} \times 5 \mathrm{~mm}$ na średnicy $\varnothing 170 \mathrm{~mm}$ na powierzchni czołowej oraz frezowanie podcięcia pod zamek obsady $8 \mathrm{~mm} \times 140 \mathrm{~mm}$ na głębokość $10 \mathrm{~mm}$.

\section{Podsumowanie}

Rezultatem pracy badawczej przeprowadzonej wspólnie przez Politechnikę Świętokrzyską w Kielcach i zakład produkcyjny Chemar Armatura było osiągnięcie trzech wskaźników technologicznych $\mathrm{w}$ postaci: redukcji masy produkowanych zasuw, redukcji czasów obróbkowych, redukcji energochłonności procesu oraz zwiększenia trwałości zasuw.

Średnia obliczona procentowa wartość redukcji masy nowych zasuw wyniosła $17,1 \%$ typoszeregu DN80 do DN300 PN40, a dla typoszeregu DN80 do DN300 PN100: 17,9\%.

Przykładowy wskaźnik redukcji czasów obróbki dla wybranego typu zasuwy DN200, PN40 wyniósł ok. 66\%. Tak dużą wartość udało się osiągnąć dzięki zastapieniu obrabiarek konwencjonalnych przez obrabiarki specjalne, sterowane numerycznie. Czas obróbki skrócił się z 10,5 h do 3,5 h.

Redukcję czasów obróbki obliczono przez porównanie czasów obróbki starej konstrukcji zasuwy w oparciu o kartę pracochłonności technologicznej i czasów obróbki nowej konstrukcji zasuwy, wyznaczonych na podstawie stworzonej $\mathrm{w}$ programie CAM technologii obróbki oraz zweryfikowanych czasów obróbki na nowych maszynach. Analiza energochłonności starego i nowego procesu pokazuje, że zużycie energii na wytworzenie korpusu w starej technologii wynosi ok. 215,35 kWh, natomiast w nowej technologii - ok. 143,5 kWh. Redukcja zapotrzebowania energii wynosi ok. 33,4\%.

\section{LITERATURA}

[1] Adamczak S., Makieła W. „Metrologia w budowie maszyn”. Wyd. II. Warszawa: Wydawnictwa Naukowo-Techniczne (2007).

[2] Adamczak S. „Pomiary geometryczne powierzchni - zarysy kształtu, falistość i chropowatość". Warszawa: Wydawnictwa Naukowo-Techniczne (2009)

[3] Adamczak S., Świderski J. „Narzędzia do analizy porównawczej stanu struktury geometrycznej powierzchni ukształtowanej toczeniem". Mechanik. 10 (2017): 906-908, DOI: https://doi.org/10.17814/mechanik.2017.10.143.

[4] Grzesik W. „Podstawy skrawania materiałów metalowych (Fundamentals of metal cutting)". Warszawa: Wydawnictwa Naukowo-Techniczne (1998).

[5] Nowakowski Ł., Miko E. „Analiza czynników wpływających na strukturę geometryczną powierzchni poddanych obróbce skrawaniem". Mechanik. 88, 8-9 (2015): 11-18, DOI: https://doi.org/ 10.17814/mechanik.2015.8-9.406

[6] Nowakowski Ł., Skrzyniarz M., Miko E. "The analysis of relative oscillation during face milling". $23^{\text {rd }}$ International Conference ENGINEERING MECHANICS. (2017): 730-733, https://www.researchgate.net/publication/340350548_ THE_ANALYSIS_OF_RELATIVE_OSCILLATION_DURING_ FACE_MILLING.

[7] Olszak W. „Obróbka skrawaniem”. Warszawa: Wydawnictwa Naukowo-Techniczne (2008)

[8] Ruszaj A. „Niekonwencjonalne metody wytwarzania elementów maszyn i narzędzi". Kraków: IOS (1999). 